DOI: 10.12731/2658-6649-2019-11-5-2-45-49

УДК 616-092.6

\title{
СОСТОЯНИЕ ГЛУТАТИОНОВОГО ЗВЕНА АНТИОКСИДАНТНОЙ ЗАЩИТЫ БОЛЬНЫХ МЕХАНИЧЕСКОЙ ЖЕЛТУХОЙ ЖЕЛЧНОКАМЕННОГО ГЕНЕЗА
}

\author{
Елманова Н.Г., Смирнова О.В.
}

Было изучено состояние глутатионового звена антиоксидантной защииты у больных механической желтухой желчнокаменного генеза. Bblявлен высокий уровень окислительного стресса и высокая активность глутатион зависимых ферментов.

Ключевые слова: механическая желтуха; антиоксидантная защита; окислительный стресс.

\section{STATE OF GLUTATHIONE ANTIOXIDANT DEFENSE OF PATIENTS WITH OBSTRUCTIVE JAUNDICE OF GALLSTONE GENESIS}

\section{Elmanova N.G., Smirnova O.V.}

The state of glutathione antioxidant defense in patients with obstructive jaundice of gallstone genesis was studied. High levels of oxidative stress and high activity of glutathione dependent enzymes have been identified.

Keywords: obstructive jaundice; antioxidant protection; oxidative stress.

\section{Введение}

Синдром механической желтухи является одним из частых осложнений желчнокаменной болезни, так при калькулезном холецистите механическая желтуха развивается примерно в 70\% случаях [1]. Тяжелое состояние таких больных обусловлено сложным патогенезом заболевания [2]. Известно, что на состояние больных с синдромом механической желтухи влияет изменения в иммунной системе, эндотоксикоз и развитие окислительного стресса $[2,3]$. 


\section{Материалы и методы исследования}

Объектом исследования были 84 больных МЖ желчнокаменного генеза, в возрасте от 29 до 69 лет Контрольную группу составили 120 практически здоровых добровольцев, сопоставимых по полу и возрасту с основной группой. Обследование больных и практически здоровых людей проводилось с разрешения этического комитета ФГБНУ ФИЦ КНЦ НИИ медицинских проблем Севера СО РАН, при этом каждый участник подписывал форму информированного согласия на обследование. Для оценки состояния антиоксидантной защиты использовался спектрофотометрический метод определения малоновго диальдегида, восстановленного глутатиона, глутатион-S-трансферазы и глутатионпероксидазы в эритроцитах и плазме крови (спектрофотометр Specol) [4]. С помощью прикладной программы Statistica 7 (StatSoft, USA) велась статистическая обработка данных.

\section{Результаты исследования}

У больных с синдромом механической желтухи желчнокаменного генеза содержание малонового диальдегида в эритроцитах и в плазме крови повышено по сравнению с группой контроля $\left(\mathrm{p}_{1-2}=0.03 * 10^{-7}\right.$, $\left.\mathrm{p}_{1-2}=0.000005\right)$.

Концентрация восстановленного глутатиона в эритроцитах была понижена по сравнению с практически здоровыми людьми $\left(\mathrm{p}_{1-2}=0.000002\right)$.

Активность глутатион-S-трансферазы была увеличена по сравнению с контрольной группой в эритроцитах и в плазме крови $\left(\mathrm{p}_{1-2}=0.000001, \mathrm{p}_{1-2}=\right.$ $\left.=0.05^{*} 10^{-7}\right)$.

В группе больных МЖ желчнокаменного генеза активность фермента глутатионпероксидазы в эритроцитах и плазме крови была увеличена по сравнению с практически здоровыми людьми $\left(\mathrm{p}_{1-2}=0.03 * 10^{-7}\right.$, $\left.\mathrm{p}_{1-2}=0.01 * 10^{-6}\right)$.

\section{Обсуждение}

Малоновый диальдегид синтезируется в клетках в результате деградации активными формами кислорода полиненасыщенных жирных кислот. Данное соединение служит маркером окислительного стресса. Уровень малонового диальдегида повышен у больных МЖ желчнокаменного генеза как в эритроцитах, так и в плазме крови, что говорит о том что не только эритроциты находятся в состоянии окислительного стресса, но и организм больных в целом. 
Сниженное содержание восстановленного глутатиона в эритроцитах и плазме крови подтверждает резвившийся окислительный стресс.

При этом повышенная активность глутатионзависимых ферментов (глутатион-S-трансфераза и глутатионпероксидаза) в эритроцитах и плазме крови увеличена, что свидетельствует о декомпенсационной работе глутатионового звена антиоксидантной защиты.

\section{Заключение}

У больных МЖ желчнокаменного генеза определялся выраженный окислительный стресс. Также глутатионовое звено антиоксидантной защиты организма не справляются с резвившимся окислительным стрессом, хотя ферменты глутатионового звена антиоксидантной защиты активны.

Информация о конфликте интересов. Авторы заявляют об отсутствии конфликта интересов.

\section{Список литературы}

1. Пасечник И.Н., Кутепов Д.Е. Печеночная недостаточность: современные методы лечения. М. 2009. 240 с.

2. Смирнова О.В., Титова Н.М., Манчук В.Т., Елманова Н.Г., Кочетова Л.В., Пахомова Р.А. Особенности клеточного звена иммунитета у больных механической желтухой доброкачественного генеза в зависимости от уровня билирубина // Фундаментальные исследования. 2015. №2-10. С. 2174-2179.

3. Смирнова О.В., Титова Н.М., Елманова Н.Г. Особенности хемилюминесцентной активности нейтрофильных гранулоцитов больных механической желтухой доброкачественного генеза // Российский иммунологический журнал. 2015. Т.9 (18). №2 (1). С. 313-315.

4. Смирнова О.В., Титова Н.М., Елманова Н.Г. Особенности проооксидантной и антиоксидантной системы у больных множественной миеломы в заивсимости от стадии заболевания // Бюллетень экспериментальной биологии и медицины. 2014. №3. Т. 157. С. 357-361.

5. Савченко А.А., Смирнова О.В., Манчук В.Т. и др. Способ прогнозирования геморрагических осложнений после химиотерапии у больных острыми лейкозами. Патент на изобретение RUS 2324190 15.02.2006.

6. Хемилюминесцентная активность нейтрофильных гранулоцитов в прогрессировании механической желтухи в зависимости от уровня билирубина и генеза желтухи. Смирнова О.В., Титова Н.М., Каспаров Э.В. и др. Медицинская иммунология. 2016. Т. 18. № 3. С. 269-278. 


\section{References}

1. Pasechnik I.N., Kutepov D.E. Pechenochnaya nedostatochnost': sovremennye metody lecheniya [Hepatic insufficiency: modern treatment methods] M.; 2009: P. 240.

2. Smirnova O.V., Titova N.M., Manchuk V.T., Elmanova N.G., Kochetova L.V., Pakhomova R.A. Osobennosti kletochnogo zvena immuniteta u bol'nyh mekhanicheskoj zheltuhoj dobrokachestvennogo geneza $\mathrm{v}$ zavisimosti ot urovnya bilirubina [Features of cellular immunity in patients with obstructive jaundice of benign genesis, depending on the level of bilirubin]; Fundamental'nye issledovaniya [Fundamental research]: 2015; №2-10: P. 2174-2179.

3. Smirnova O.V., Titova N.M., Elmanova N.G. Osobennosti hemilyuminescentnoj aktivnosti nejtrofil'nyh granulocitov bol'nyh mekhanicheskoj zheltuhoj dobrokachestvennogo geneza [Features of the chemiluminescent activity of neutrophilic granulocytes in patients with obstructive jaundice of benign genesis]: Rossijskij immunologicheskij zhurnal [Russian immunological journal]: 2015; V.9 (18); №2 (1): P. 313-315.

4. Smirnova O.V., Titova N.M., Elmanova N.G. Osobennosti proooksidantnoj i antioksidantnoj sistemy u bol'nyh mnozhestvennoj mielomy v zaivsimosti ot stadii zabolevaniya [Features of proooxidant and antioxidant system in patients with multiple myeloma, depending on the stage of the disease]: Byulleten' eksperimental'noj biologii i mediciny [Bulletin of Experimental Biology and Medicine]. 2014; №3; V. 157: P. 357-361.

5. Savchenko A.A., Smirnova O.V., Manchuk V.T. et al. Sposob prognozirovaniya gemorragicheskih oslozhnenij posle himioterapii u bol'nyh ostrymi lejkozami [A method for predicting hemorrhagic complications after chemotherapy in patients with acute leukemia]. Patent na izobretenie RUS 2324190 15.02.2006.

6. Smirnova O.V., Titova N.M., Kasparov E.V. et al. Hemilyuminescentnaya aktivnost' nejtrofil'nyh granulocitov v progressirovanii mekhanicheskoj zheltuhi v zavisimosti ot urovnya bilirubina i geneza zheltuhi [Chemiluminescent activity of neutrophil granulocytes in the progression of obstructive jaundice, depending on the level of bilirubin and the genesis of jaundice]. Medicinskaya immunologiya [Medical immunology]. 2016. T. 18. № 3. S. 269-278.

\section{ДАННЫЕ ОБ АВТОРАХ}

Елманова Нина Гергиевна, м.н.с., лаборатория клинической патофизиологии

Федеральное государственное бюджетное научное учреждение «Федеральные исследовательский иентр «Красноярский научный 
иентр Сибирского отделения Российской академии наук» - обособленное подразделение «Научно-исследовательский институт медицинских проблем Севера»

ул. Партизана Железняка, 32, г. Красноярск, 660022, Российская Федерачия

elm-nina@yandex.ru

Смирнова Ольга Валентиновна, д.м.н., доцент, профессор, заведующая лабораторией клинической патофизиологии Федеральное государственное бюджетное научное учреждение «Федеральные исследовательский иентр «Красноярский научныии иентр Сибирского отделения Российской академии наук» - обособленное подразделение «Научно-исследовательский институт медичинских проблем Севера»

ул. Партизана Железняка, 32, г. Красноярск, 660022, Российская Федерация

ovsmirnova71@mail.ru

\section{DATA ABOUT THE AUTHORS}

EImanova Nina Georgievna, Junior Researcher of laboratory of clinical pathophysiology

Research Institute of Medical Problems of the North of the Federal Research Center Krasnoyarsk Scientific Center of the Siberian Branch of the Russian Academy of Sciences

3g, Partizan Zheleznyak Str., Krasnoyarsk, 660022, Russian Federation elm-nina@yandex.ru

Smirnova Olga Valentinovna, Doctor of Medical Sciences, Associate Professor, Professor, Head laboratory of clinical pathophysiology Research Institute of Medical Problems of the North of the Federal Research Center Krasnoyarsk Scientific Center of the Siberian Branch of the Russian Academy of Sciences

3g, Partizan Zheleznyak Str., Krasnoyarsk, 660022, Russian Federation ovsmirnova71@mail.ru 